\title{
Parental Age and Birth Order in Alzheimer's disease: A Case-Control Study in the Saguenay-Lac-St-Jean Area (Quebec, Canada)
}

\author{
M. De Braekeleer, S. Froda, D. Gautrin, H. Tetreault and D. Gauvreau
}

\begin{abstract}
Parental age at the time of birth of 133 clinically diagnosed Alzheimer patients from the Saguenay-LacSt-Jean area (Quebec, Canada) were compared with those of 6 control groups formed out a population registry. The birth order of the Alzheimer patients was also analyzed. The results did not show any parental age or birth order effect, which is in agreement with previous reports. The importance of control selection in such studies is stressed.

RÉSUMÉ: L'âge des parents, le rang de naissance et la maladie d'Alzheimer: une étude faite dans la region du Saguenay-Lac-St-Jean (Québec, Canada) On a calculé l'âge des parents au moment de la naissance de 133 patients atteints de la maladie d'Alzheimer et diagnostiqués cliniquement dans la région du Saguenay-Lac-St-Jean (Québec, Canada) en utilisant un régistre de population. Le rang de naissance des patients a aussi été déterminé. Les résultats ont montré qu'il n'y avait pas de relation entre l'âge des parents et le rang de naissance et la maladie d'Alzheimer, ce qui est en accord avec les résultats obtenus par d'autres chercheurs. L'importance de la sélection des groupes controllés dans de telles études est soulignée.
\end{abstract}

Can. J. Neurol. Sci. 1988; 15:139-141

Alzheimer's disease (AD) is a progressive dementing illness that manifests itself in mid or late adulthood. It is the most common form of dementing disorder in the elderly. ${ }^{1}$

Previous pathological and epidemiological findings have established an association between Alzheimer's disease and Down's syndrome (DS) ${ }^{2,3}$ In particular, Heston et al ${ }^{3}$ found an increased prevalence of $\mathrm{DS}$ among relative of $\mathrm{AD}$ patients as compared to the one expected in the general population. More recently, the B amyloid gene, which is an important component of the plaques in $\mathrm{AD}$ and $\mathrm{DS}$, was mapped on chromosome 21 . $^{4-6}$

Because parental age, and more particularly maternal age, and birth order are well-known risk factors in Down's syndrome, ${ }^{7,9}$ these findings lead a number of researchers to investigate a possible relationship between $A D$ and parental age or birth order. ${ }^{10-17}$ No paternal effect was found but analyses of the maternal age and birth order showed conflicting results.

The present study was undertaken to determine whether parental age and birth order were risk factors in a population of
133 clinically diagnosed Alzheimer patients from the SaguenayLac-St-Jean (SLSJ) area (Quebec, Canada).

\section{Materials AND MethodS}

The Saguenay-Lac-St-Jean area is a quite isolated region located 125 miles North-East of Quebec City. The region was opened to white settlement in the 1840 s. The population rose quickly by immigration but mainly by natural increase. At the present time, some 300,000 people live in the SLSJ area.

Since 1972 , a population registry has been constructed. It contains over 700,000 birth, marriage, and death certificates and is completed till $1971 .{ }^{18}$ Several parameters are recorded for each individual, notably dates and places of birth, marriage and death, socioeconomic status, successive residences. All the families are reconstructed and genealogies can be automatically generated. ${ }^{19}$

From SOREP, Université du Québec à Chicoutimi, Chicoutimi, Québec (Dr. Braekeleer); Département de Mathématiques et d'Informatique, Université du Québec à Montréal, Québec (Dr. Froda); Institut National de Recherche Scientifique (INRS-Santé), Pointe-Claire, Québec, (Drs. Gautrin, Tetrault, Gauvreau)

Received August 5, 1987. Accepted December 22, 1987.

Reprint requests to: Dr. M. De Braekeleer, SOREP, Université du Québec à Chicoutimi, 555, Boulevard de l'Université, Chicoutimi, Québec, Canada G7H 2B1 
A registry of over 400 presumptive cases of senile dementia of the Alzheimer type from the SLSJ region is now being screened for Alzheimer's disease (IMAGE project). So far, 133 cases have been classified as definite, probable or possible AD following the recommendations of the NINCDS-ADRDA work group. ${ }^{20}$

A method devised by Haldane and Smith ${ }^{21}$ was used to decide whether, in our 133 sibships, AD patients tended to be born later. The Haldane-Smith test is based on the sum of the birth ranks of all affected members in all sibships. Hence, this test uses only the affected sibships and no controls. In situations where there is no information on some sibs, the method proposes to eliminate these "unspecified" members. For the present analysis, the deceased sibs and those younger than 40 years of age were considered "unspecified" as their disease status was in fact unknown.

Maternal age was known in 120 cases and paternal age in 122 cases. The mean parental age for the normal sibs of the Alzheimer patients was calculated using the population registry. Parental age at the time of birth of the AD patients' spouses was also determined. Six control groups were created, using the population registry. Controls 1-2-3 were matched on the date of marriage of the parents of the Alzheimer patients ( + or -5 days), their socioeconomic status as defined by the father's profession, the parents' residence and the birth rank of the AD patients. Controls 4-5-6 were randomly selected births matched on sex and year of birth of the Alzheimer patients as well as the socioeconomic status of the parents. The statistical analysis was performed using the Student's paired t test, two-tailed.

\section{Results}

The Haldane-Smith test was applied for testing no birth order effect against a later born alternative. No significant result was found (test statistic $=-3.075, \mathrm{p}>0.99$ ).

Table 1 shows the parental age at time of birth for Alzheimer patients, normal siblings, spouses, and controls. Both maternal and paternal mean ages at the time of birth of the Alzheimer patients were found to be significantly lower than their ages at the time of birth of the normal siblings (respectively $F=2.64, p$ $<0.001$ and $F=2.25, P=0.001$ ). No significant difference was found between parental age at the time of birth of the Alzheimer patients and their spouses, or any of the 6 control groups $(P>$ 0.10 ).

Table 1: Parental age at time of birth for Alzheimer patients, normal siblings, spouses and controls.

\begin{tabular}{lcccc}
\hline \hline & \multicolumn{2}{c}{ Mother's age } & \multicolumn{2}{c}{ Father's age } \\
& $\begin{array}{c}\text { Mean } \\
\text { (years) }\end{array}$ & $\begin{array}{c}\text { S.D. } \\
\text { (years) }\end{array}$ & $\begin{array}{c}\text { Mean } \\
\text { (years) }\end{array}$ & $\begin{array}{c}\text { S.D. } \\
\text { (years) }\end{array}$ \\
\hline Alzheimer patients & 29.4 & 6.7 & 32.6 & 7.5 \\
Normal siblings & $31.5^{*}$ & 4.1 & $34.9^{*}$ & 5.0 \\
Spouses & 29.5 & 6.1 & 33.4 & 6.7 \\
Controls 1 & 29.7 & 4.2 & 33.3 & 4.7 \\
Controls 2 & 30.1 & 4.3 & 33.5 & 4.3 \\
Controls 3 & 29.2 & 4.3 & 33.4 & 5.6 \\
Controls 4 & 30.2 & 4.5 & 33.2 & 7.0 \\
Controls 5 & 30.0 & 4.2 & 32.5 & 5.1 \\
Controls 6 & 29.1 & 5.7 & 32.2 & 6.8 \\
\hline
\end{tabular}

$* \mathrm{p}<0.05$

\section{Discussion}

Previous analyses of the relationship between birth order and Alzheimer's disease has led to negative or indefinite conclusions. Larson et $\mathrm{al}^{10}$ found that 199 of the $\mathbf{4 0 8}$ patients with senile dementia belonged to the first half of the birth series and the remaining 209 to the second half of the birth series. Using the method of Carothers et $\mathrm{al}^{22}$ Whalley et al ${ }^{11}$ did not find any significant birth order effect. Amaducci et al ${ }^{16}$ found a borderline significant relation between a high birth rank and AD. White et al ${ }^{17}$ showed that the average birth order of the 126 autopsy-proven Alzheimer patients was significantly less than the average birth order of the controls selected among the births recorded in the Anoka county (Minnesota). However, the average birth order for the Alzheimer patients was not significantly different from the expected average computed assuming random distribution of the $\mathrm{AD}$ cases throughout the sibship.

Our results did not show any evidence of a relationship between a high birth order and AD. In fact, it was noted that testing no birth order effect against an early-born alternative would have given highly significant results $(P<0.001)$. White et $\mathrm{al}^{17}$ suggested that their result was probably due to the control families being larger than the AD families. However, the present analysis was based only on the affected sibships and, therefore, there is no possible bias due to the choice of the control families. An early-born effect may sometimes be explained by the lack of ascertainment of younger cases (secondary cases) who have not yet developed the disease or been screened. The use of the Haldane-Smith method that allowed us to eliminate the very young ones in the computing (less than 40 years old) helped reduce this problem.

A younger maternal age at the time of birth of the Alzheimer patients than of the normal siblings ( 29.4 versus 31.5 years) was found. The direction of this difference is opposite to what would have to be expected if there was a maternal age effect on $\mathrm{AD}$. The difference in the mean maternal age at the time of birth of the Alzheimer patients compared with that of the spouses and controls was not statistically significant. Similar results were already reported by Heyman et $\mathrm{al}^{13}$ who compared maternal age at the time of birth of 36 clinically diagnosed and patients with their spouses and by Corkin et $\mathrm{al}^{14}$ who compared the maternal age at the time of birth of 37 clinically diagnosed Alzheimer patients with the age at birth of 34 controls of comparable age and socioeconomic status. A similar conclusion was reached by English and Cohen ${ }^{15}$ who compared 64 clinically diagnosed AD cases with their spouses and spouses of 87 patients with Parkinson disease. White et a ${ }^{17}$ did not find any significant difference in maternal age at the time of birth of 112 AD patients, most of them autopsy-proven, their normal siblings, and 200 randomly selected births in Anoka county (Minnesota). Cohen et al ${ }^{12}$ found an association between maternal age and $\mathrm{AD}$ but their controls were not matched on factors such as socioeconomic status. Amaducci et $\mathrm{al}^{16}$ found a maternal age effect for $A D$ but their controls were not matched on the $A D$ patients' characteristics.

A younger paternal age at the time of birth of the Alzheimer patients than of the normal siblings ( 32.6 versus 34.9 years) was found. The mean age of fathers at the time of birth of AD cases was not significantly different from the mean age of the spouses or the controls. Such findings were already reported by several workers. ${ }^{13,14,16,17}$ 
Whalley et al" compared 69 autopsy-proven AD cases with 207 unrelated controls matched for year of birth, sex and paternal occupation. They found a significant increase in maternal and paternal ages for the AD cases. However, they did not find any significant parental age effect when using the method of Carothers $\mathrm{et} \mathrm{al}^{22}$ which estimates a relation risk as a function of parental age and birth order and, therefore, used the siblings as controls.

In conclusion, the controversial results described in the literature seem to be a consequence of control selection. The studies that used the siblings or the spouses as controls or matched the controls on socioeconomics status did not show any parental age or birth order effects for Alzheimer's disease. Our results, which are based on six different control groups, are in agreement with these conclusions.

\section{ACKNOWLEDGEMENTS}

This study was supported by a research grant from the Medical Research Council (MRC) of Canada. The authors are grateful to Drs. Jean Mathieu and Camil Boily who revised the diagnostics.

\section{REFERENCES}

1. Mortimer JA, Schuman LM, eds. The epidemiology of dementia. New York: Oxford University Press, 1983.

2. Ellis WG, McCulloch JR, Corley CL. Presenile dementia in Down's syndrome: ultrastructural identity with Alzheimer's disease. Neurology 1974; 24: 101-106.

3. Heston LL, Mastri AR, Anderson VE, et al. Dementia of the Alzheimer type: clinical genetics, natural history, and associated conditions. Arch Gen Psychiatry 1981; 38: $1085-1090$.

4. Goldgaber D, Lerman MI, McBride OW, et al. Characterization and chromosomal localization of a cDNA encoding brain amyloid of Alzheimer's disease. Science 1987; 235: 877-880.

5. Tanzi RE, Gusella JF, Watkins PC, et al. Amyloid B protein gene: cDNA, mRNA distribution, and genetic linkage near the Alzheimer locus. Science 1987; 235: 880-884.
6. St George-Hyslop PH, Tanzi RE, Polinsky RJ, et al. The genetic defect causing familial Alzheimer's disease maps on chromosome 21 . Science $1987 ; 235: 885-890$.

7. Penrose LS. The relative effects of paternal and maternal age in mongolism. J Genetics 1933; 27: 219-233.

8. Erickson JD. Down's syndrome, paternal age, maternal age and birth order. Ann Hum Genet 1978; 41: 289-293.

9. Stene J, Stene E. Statistical methods for detecting a moderate paternal age effect on the incidence of a disorder when a maternal one is present. Ann Hum Genet 1977; 40: 343-347.

10. Larsson T, Sjogren T, Jacobson G. Senile dementia. Clinical sociomedical and genetic study. Acta Psychiatr Scand 1963;39 (Supp) 167): $190-191$.

11. Whalley LJ, Carothers AD, Collyer S, et al. A study of familial factors in Alzheimer's disease. Br J Psychiatry 1982; 140: 249-256.

12. Cohen D, Eisdorfer C, Leverenz J. Alzheimer's disease and maternal age. J Am Geriatr Soc 1982; 30: 656-659.

13. Heyman A, Wilkinson WE, Hurwitz BJ, et al. Alzheimer's disease: genetic aspects and associated clinical disorders. Ann Neurol $1983 ; 14: 507-515$.

14. Corkin S, Growdon JH, Rasmussen SL. Parental age as a risk factor in Alzheimer's disease. Ann Neurol 1983; 13: 674-676.

15. English D, Cohen D. A case-control study of maternal age in Alzheimer's disease. J Am Geriatr Soc 1985; 33: 167-169.

16. Amaducci LA, Fratiglioni L, Rocca WA, et al. Risk factors for clinically diagnosed Alzheimer's disease: a case-control study of an Italian population. Neurology 1986; 36: 922-931.

17. White JA, McGue M, Heston LL. Fertility and parental age in Alzheimer disease. J Gerontol 1986; 41: 40-43.

18. Bouchard G, Pouyez C, Roy R. L'avenir des fichiers de population dans les sciences humaines: le projet de fichier-reseau de la population saguenayenne. Etudes Canadiennes 1980; 9: 31-45.

19. Bouchard G, Roy R, Casgrain B, eds. Reconstruction automatique des familles. Le systeme SOREP. Chicoutimi: Presses de l'Université du Québec à Chicoutimi, 1985.

20. McKhann G, Drachman D, Folstein M. Clinical diagnosis of Alzheimer's disease: report of the NINCDS-ADRDA work group under the auspices of Department of Health and Human Services Task Force on Alzheimer's disease. Neurology 1985; 34: 939-944.

21. Haldane JBS, Smith CAB. A simple exact test for birth-order effect. Ann Eugenics 1947; 14: 117-124.

22. Carpthers AD, Collyer S, De Mey R, et al. Parental age and birth order in the aetiology of some sex chromosome aneuploidies. Ann Hum Genet 1978; 41: 277-287. 